\title{
PELATIHAN PEMBUATAN DAN IMPLEMENTASI PERANGKAT PEMBELAJARAN BERORIENTASI I2M3 DALAM UPAYA PENINGKATAN PROFESIONALISME GURU SD DI GUGUS XIV KECAMATAN BULELENG
}

\author{
oleh, \\ I Gede Margunayasa \\ Jurusan PGSD \\ Fakultas Ilmu Pendidikan \\ Universitas Pendidikan Ganesha
}

\begin{abstract}
ABSTRAK
Tujuan dari kegiatan pengabdian ini, yaitu 1) untuk meningkatkan pemahaman guruguru di Gugus XIV Kecamatan Buleleng dalam pembuatan perangkat pembelajaran berbasis I2M3, 2) untuk meningkatkan keterampilan guru-guru di Gugus XIV Kecamatan Buleleng dalam mengimplementasikan perangkat pembelajaran berbasis I2M3. Pendekatan yang digunakan dalam pendampingan adalah pendekatan kebiasaan dengan menerapkan metode drill. Peserta yang mengikuti kegiatan ini berjumlah 27 orang guru dari SD di Gugus XIV Kecamatan Buleleng. Hasil dari kegiatan pengabdian ini yaitu ditinjau dari kegiatan pelatihan yang telah dilakukan, seluruh peserta telah mengikuti dengan baik. Peserta telah memahami tentang pembelajaran berorientasi I2M3 sesuai Permendiknas No. 41 Tahun 2007. Peserta telah mampu menghasilkan perangkat pembelajaran berorientasi I2M3. Dari segi implementasi perangkat, peserta mampu memgimplementasikan RPP pembelajaran berorientasi I2M3 yang telah dibuat dan dapat menciptakan suasana pembelajaran yang I2M3. Ditinjau dari jalannya acara pelatihan pembuatan dan implementasi perangkat pembelajaran berorientasi I2M3, acara telah berjalan dengan lancar dan tepat waktu. Peserta pun merasa puas terhadap acara yang diikuti dan servis yang didapatkan. Akan tetapi, peserta masih bermasalah dalam pengetikan dokumen. Peserta mengaku kesulitan untuk pengetikan pada komputer. Dengan demikian, peserta mengharapkan diadakannya pelatihan mengenai penggunaan microsoft word untuk menunjang tugas-tugas guru.
\end{abstract}

Kata kunci: pelatihan, perangkat pembelajaran, I2M3, profesionalisme guru

\section{Pendahuluan}

Pada tahun 2005, Pemerintah mengeluarkan Peraturan Pemerintah (PP) nomor 19 tentang Standar Nasional Pendidikan (SNP). Standar Nasional Pendidikan meliputi 8 (delapan) standar, yaitu: (1) standar isi; (2) standar proses; (3) standar kompetensi lulusan; (4) standar pendidikan dan tenaga kependidikan; (5) standar sarana dan prasarana; (6) standar pengelolaan; (7) standar pembiayaan; dan (8) standar penilaian. Standar-standar tersebut adalah standar minimal, artinya satuan pendidikan dapat mencapai standar yang lebih tinggi dari standar nasional tersebut. 
Standar yang tercantum dalam PP tersebut masih bersifat global. Untuk memerincinya diperlukan Peraturan Menteri Pendidikan Nasional (Permendiknas). Jumlah standar nasional ada delapan, sehingga minimal dibutuhkan delapan Permendiknas. Pada tahun 2005 belum satupun Permendiknas yang dihasilkan. Padahal Pemerintah mengharap setiap satuan pendidikan segera menyusun program untuk mencapainya. Sebagai pedoman sementara, sampai Permendiknasnya dikeluarkan, Pemerintah menyusun Standar Pelayanan Minimal (SPM).

Mendiknas mulai mengeluarkan Permendiknas pada tahun 2006, yaitu Permendiknas nomor 22 tentang standar isi, nomor 23 tentang standar kompetensi lulusan, dan 24 tentang pelaksanaannya. Permendiknas nomor 22, dan 23 mengamanatkan kepada setiap satuan pendidikan untuk menyusun kurikulum satuan pendidikannya sendiri-sendiri, yang dikenal dengan istilah kurikulum tingkat satuan pendidikan (KTSP). Namun perlu diingat, Permendiknas tersebut hanya memberikan rambu-rambu tentang standar isi dan standar kompetensi lulusan atau kurikulumnya. Bagaimana proses pembelajaran dan penilaiannya, masih diperlukan dua Permendiknas lagi, yaitu Permendiknas tentang standar proses dan Permendiknas tentang standar penilaian. Pada tahun 2007, dikeluarkan Permendiknas nomor 20 tentang Standar Penilaian, dan Permendiknas nomor 41 tentang Standar Proses. Permendiknas nomor 41, memberikan rambu-rambu proses pembelajaran pada KTSP, dan Permendiknas nomor 20 memberikan rambu-rambu penilaian KTSP. Mengacu pada Permendiknas nomor 41 tahun 2007 bahwa proses pembelajaran yang dilaksanakan oleh guru mengacu pembelajaran yang interaktif, inspiratif, menyenangkan, menantang, dan memotivasi (I2M3).

Pembelajarana I2M3 adalah pembelajaran yang berlangsung secara interaktif, inspiratif, menyenangkan, menantang, memotivasi peserta didik untuk berpartisipasi aktif, serta memberikan ruang yang cukup bagi prakarsa, kreativitas, dan kemandirian sesuai dengan bakat, minat, dan perkembangan fisik serta psikologis peserta didik (PP 19/2005, pasal 19 ayat 1). Pembelajaran I2M3 dimulai dengan membuat perencanaan. Perencanaan berupa silabus dan rencana pelaksanaan pembelajaran (RPP). Pelaksanaan pembelajaran I2M3 mengacu pada ketentuan-ketentuan sebagai berikut: (1) jumlah siswa per rombongan belajar (kelas) untuk SD/MI maksimal 28 siswa, SMP/MTs, SMA/MA, dan SMK/MAK maksimal 32 siswa; (2) beban mengajar guru sekurang- 
kurangnya 24 jam, yang meliputi kegiatan pokok merencanakan pembelajaran, melaksanakan pembelajaran, menilai hasil pembelajaran, membimbing dan melatih peserta didik, serta melaksanakan tugas tambahan lainnya (Permendiknas nomor 41/2007).

Ditinjau dari sisi pengelolaan kelas, dalam pembelajaran I2M3 tampak sebagai berikut: (1) guru mengatur tempat duduk sesuai dengan karakteristik peserta didik dan mata pelajaran, serta aktivitas pembelajaran yang akan dilakukan; (2) volume dan intonasi suara guru dalam proses pembelajaran harus dapat didengar dengan baik oleh peserta didik; (3) tutur kata guru santun dan dapat dimengerti oleh peserta didik; (4) guru menyesuaikan materi pelajaran dengan kecepatan dan kemampuan belajar peserta didik; (5) guru menciptakan ketertiban, kedisiplinan, kenyamanan, keselamatan, dan kepatuhan pada peraturan dalam menyelenggarakan proses pembelajaran; (6) guru memberikan penguatan dan umpan balik terhadap respon dan hasil belajar peserta didik selama proses pembelajaran berlangsung; (7) guru menghargai peserta didik tanpa memandang latar belakang agama, suku, jenis kelamin, dan satus sosial ekonomi; (8) guru menghargai pendapat peserta didik; (9) guru memakai pakaian yang sopan, bersih, dan rapi; (10) pada tiap awal semester, guru menyampaikan silabus mata pelajaran yang diampunya; dan (11) guru memulai dan mengakhiri proses pembelajaran sesuai dengan waktu yang dijadwalkan (Permendiknas nomor 41/2007).

Pelaksanaan pembelajaran I2M3, menurut Permendiknas nomor 41/2007 dibagi menjadi 3 tahap, yaitu kegiatan pendahuluan, kegiatan inti, dan kegiatan penutup. Pada kegiatan pendahuluan guru melakukan hal-hal sebagai berikut: (1) menyiapkan peserta didik secara psikis dan fisik untuk mengikuti proses pembelajaran; (2) mengajukan pertanyaan-pertanyaan yang mengaitkan pengetahuan sebelumnya dengan materi yang akan dipelajari; (3) menjelaskan tujuan pembelajaran atau kompetensi dasar yang akan dicapai; dan (4) menyampaikan cakupan materi dan menjelaskan uraian kegiatan sesuai silabus.

Kegiatan inti meliputi proses eksplorasi, elaborasi, dan konfirmasi. Dalam kegiatan eksplorasi guru melakukan hal-hal sebagai berikut; (1) melibatkan peserta didik mencari informasi yang luas dan dalam tentang topik/tema materi yang akan dipelajari dengan menerapkan prinsip alam takambang jadi guru dan belajar dari aneka sumber; (2) menggunakan beragam pendekatan pembelajaran, media pembelajaran, dan sumber 
belajar lain; (3) menfasilitasi terjadinya interaksi antar peserta didik serta antara pendidik dengan guru, lingkungan, dan sumber belajar lainnya; (4) melibatkan peserta didik secara aktif dalam setiap kagitan pembelajaran, dan (5) menfasilitasi peserta didik melakukan percobaan di laboratorium, studio, atau lapangan.

Pada tahap elaborasi, guru melakukan hal-hal sebagai berikut: (1) membiasakan peserta didik membaca dan menulis yang beragam melalui tugas-tugas tertentu yang bermakna; (2) memfasilitasi peserta didik melalui pemberian tugas, diskusi, dan lainlain untuk memunculkan gagasan baru baik secara lisan maupun tertulis; (3) memberi kesempatan untuk berpikir, menganalisis, menyelesaikan masalah, dan bertindak tanpa rasa takut; (4) memfasilitasi peserta didik dalam pembelajaran kooperatif dan kolaboratif; (5) memfasilitasi peserta didik berkompetisi secara sehat untuk meningkatkan prestasi belajar; (6) menfasilitasi peserta didik membuat laporan eksplorasi yang dilakukan baik lisan maupun tertulis, secara individu maupun kelompok; (7) menfasilitasi peserta didik untuk manyajikan hasil kerja individual maupun kelompok; (8) menfasilitasi peserta didik melakukan pameran, turnamen, festival, serta produk yang dihasilkan; (9) menfasilitasi peserta didik melakukan kegiatan yang menumbuhkan kebanggaan dan rasa percaya diri peserta didik.

Dalam kegiatan konfirmasi, guru: (1) memberikan umpan balik positif dan penguatan dalam bentuk lisan, tulisan, isyarat, maupun hadiah terhdap keberhasilan peserta didik; (2) memberikan konfirmasi terhadap hasil eksplorasi dan elaborasi peserta didik melalui berbagai sumber; (3) memfasilitasi peserta didik melakukan refleksi untuk memperoleh pengalaman belajar yang telah dilakukan; dan (4) menfasilitasi peserta didik untuk memperoleh pengalaman yang bermakna dalam mencapai kompetensi dasar, sehingga guru berfungsi sebagai nara sumber dan fasilitator dalam menjawab pertanyaan-pertanyaan peserta didik yang menghadapi kesulitan, dengan menggunakan bahasa yanag baku dan benar; membantu menyelesaikan masalah; memberi acuan agar peserta didik dapat melakukan pengecekan hasil eksplorasi; memberi informasi untuk bereksplorasi lebih jauh; dan memberikan motivasi kepada peserta didik yang kurang atau belum berpartisipasi aktif.

Dalam kegiatan penutup guru: (1) bersama-sama dengan peserta didik dan/atau sendiri membuat rangkuman/simpulan pelajaran; (2) melakukan penilaian dan/atau refleksi terhadap kegiatan yang sudah dilaksanakan secara konsisten dan terprogram; (3) 
memberikan umpan balik baik proses dan hasil pembelajaran; (4) merencanakan kegiatan tindak lanjut dalam bentuk pembelajaran remidi, program pengayaan, layanan konseling dan/atau memberikan tugas baik tugas individu maupun kelompok sesuai dengan hasil belajar peserta didik; dan (5) menyampaikan rencana pembelajaran pada pertemuan berikutnya.

Pembelajaran I2M3 tidak dapat optimal jika guru menerapkan metode pembelajaran tradisional yang berpusat pada guru (teacher center). Guru hendaknya mengembangkan metode atau model pembelajaran yang berpusat pada siswa (student center), mengaitkan pembelajaran dengan dunia nyata siswa (contextual), siswa belajar memecahkan masalah dalam kehidupan nyata (Problem-based learning), dan siswa belajar dalam kelompok-kelompok kecil secara kolaboratif (cooperative learning). Metode atau model pembelajaran yang demikian biasanya disebut pembelajaran inovatif. Guru dapat mengunakan salah model pembelajaran yang lazim berkembang di Indonesia, yaitu: (1) pengajaran langsung (Direct Instruction); (2) pembelajaran kooperatif (Cooperative Learning); dan (3) pembelajaran berbasis masalah (Problem Base Learning) (Arends, 2004; Nur, 2004; dan Slavin, 1995).

Jika seorang guru sudah bisa menerapkan pembelajaran I2M3 dalam proses belajar mengajar tentunya hal ini akan dapat meningkatkan kompetensi seorang guru, terutama kompetensi paedagogiknya. Kompetensi paedagogik seperti yang dijelaskan dalam Peraturan Pemerintah RI No 19 Tahun 2005 meliputi kemampuan mengelola pembelajaran yang meliputi pemahaman terhadap peserta didik, perancangan dan pelaksanaan pembelajaran, evaluasi hasil belajar, dan pengembangan peserta didik untuk mengaktualisasikan berbagai potensi yang dimilikinya. Kompetensi paedagogik ini berkaitan pada saat guru mengadakan proses belajar mengajar di kelas. Mulai dari membuat skenario pembelajaran memilih metode, media, juga alat evaluasi bagi anak didiknya. Karena bagaimanapun dalam proses belajar mengajar sebagian besar hasil belajar peserta didik ditentukan oleh peranan guru. Guru yang cerdas dan kreatif akan mampu menciptakan suasana belajar yang efektif dan efisien sehingga pembelajaran tidak berjalan sia-sia.

Berdasarkan uraian latar tersebut, tujuan dari pelaksanaan P2M ini adalah 1) untuk meningkatkan pemahaman guru-guru di Gugus XIV Kecamatan Buleleng dalam pembuatan perangkat pembelajaran berbasis I2M3 dan 2) untuk meningkatkan 
keterampilan guru-guru di Gugus XIV Kecamatan Buleleng dalam mengimplementasikan perangkat pembelajaran berbasis I2M3. Adapun manfaat dari pelaksanaan P2M ini adalah bagi guru, memperoleh pengetahuan berkaitan pembelajaran yang diisyaratkan dalam Permendiknas No. 41 Tahun 2007 tentang pembelajaran I2M3. Selain itu, guru-guru akan memperoleh pengalaman dalam membuat dan mengimplementasikan perangkat pembelajaran I2M3 di sekolahnya masing-masing. Bagi pengawas sekolah, memperoleh pengetahuan tambahan tentang pembelajaran I2M3 dan sharing pengalaman berkaitan dengan hal tersebut. Bagi Unit Pengelola Pendidikan, dapat merekam (mengarsip) perangkat pembelajaran I2M3 yang dihasilkan, yang nantinya dapat dikembangkan di seluruh gugus yang ada di Kecamatan Buleleng.

\section{Metode Pelaksanaan Pengabdian}

Permasalahan yang telah dirumuskan di atas dapat dipecahkan secara strategis dengan meningkatkan pemahaman dan keterampilan guru sekolah dasar untuk membuat dan mengimplementasikan pembelajaran I2M3. Dengan demikian, bentuk kegiatan pengabdian yang dilakukan adalah sebagai berikut. (a) Pelatihan pembuatan perangkat pembelajaran berbasis I2M3 sesuai tuntutan Permendiknas No. 41 Tahun 2007 dengan melibatkan guru-guru sekolah dasar yang ada di gugus XIV Kecamatan Buleleng. Metode yang digunakan dalam pelatihan adalah ceramah, tanya jawab, diskusi, penugasan, dan simulasi, dan (b) Pendampingan pembuatan dan implementasi perangkat pembelajaran I2M3 sesuai Permendiknas No. 41 Tahun 2007 yang dilakukan oleh guru. Pendekatan yang digunakan dalam pendampingan adalah pendekatan kebiasaan dengan menerapkan metode drill.

Mitra pelaksanaan program ini adalah guru-guru SD di gugus XIV Kec. Buleleng yang berjumlah 27 orang guru. Partisipasi mitra dalam pelaksanaan program ini sebagai peserta yang menerima pelatihan dan pendampingan dari tim pelaksana program. Dalam melaksanakan P2M ini, dilakukan kerjasama antara Lembaga Pengabdian Masyarakat (LPM) Undiksha dengan unit pelaksana pendidikan (UPP) Kec. Buleleng dan Gugus XIV Kecamatan Buleleng. Kerjasama ini dilakukan dalam hal perizinan kegiatan, surat menyurat, serta hasil dari kegiatan. Untuk mengevaluasi program P2M yang dilaksanakan melalui Post-test atau tes akhir yang dilaksanakan setelah pelatihan dan 
penilaian produk (perangkat pembelajaran I2M3) dan penilaian simulasi/implementasi perangkat pembelajaran.

\section{Hasil dan Pembahasan}

Secara umum, program telah berjalan dengan lancar. Ditinjau dari kegiatan pelatihan, seluruh peserta telah mengikuti dengan baik. Peserta telah memahami tentang pembelajaran berorientasi I2M3 sesuai Permendiknas No. 41 Tahun 2007. Peserta telah mampu menghasilkan perangkat pembelajaran berorientasi I2M3. Dari segi implementasi perangkat, peserta mampu memgimplementasikan RPP pembelajaran berorientasi I2M3 yang telah dibuat dan dapat menciptakan suasana pembelajaran yang I2M3. Pembelajarana I2M3 adalah pembelajaran yang berlangsung secara interaktif, inspiratif, menyenangkan, menantang, memotivasi peserta didik untuk berpartisipasi aktif, serta memberikan ruang yang cukup bagi prakarsa, kreativitas, dan kemandirian sesuai dengan bakat, minat, dan perkembangan fisik serta psikologis peserta didik (PP 19/2005, pasal 19 ayat 1). Pelaksanaan pembelajaran I2M3 mengacu pada ketentuanketentuan sebagai berikut: (1) jumlah siswa per rombongan belajar (kelas) untuk SD/MI maksimal 28 siswa, SMP/MTs, SMA/MA, dan SMK/MAK maksimal 32 siswa; (2) beban mengajar guru sekurang-kurangnya 24 jam, yang meliputi kegiatan pokok merencanakan pembelajaran, melaksanakan pembelajaran, menilai hasil pembelajaran, membimbing dan melatih peserta didik, serta melaksanakan tugas tambahan lainnya (Permendiknas nomor 41/2007).

Ditinjau dari sisi pengelolaan kelas, guru dalam melaksanakan pembelajaran I2M3 tampak sebagai berikut: (1) guru mengatur tempat duduk sesuai dengan karakteristik siswa dan mata pelajaran, serta aktivitas pembelajaran yang dilakukan; (2) volume dan intonasi suara guru dalam proses pembelajaran sudah sangat bagus sehingga dapat didengar dengan baik oleh siswa; (3) tutur kata guru pelan, santun, dan dapat dimengerti oleh siswa; (4) guru menyesuaikan materi pelajaran dengan kemampuan belajar siswa; (5) di dalam kelas guru menciptakan ketertiban, kedisiplinan, kenyamanan, keselamatan, dan kepatuhan pada peraturan dalam menyelenggarakan proses pembelajaran; (6) guru selalu memberikan penguatan dan umpan balik terhadap respon dan hasil belajar siswa selama proses pembelajaran berlangsung; (7) guru selalu menghargai pendapat siswa tanpa memandang latar belakang agama, suku, jenis 
kelamin, dan satus sosial ekonomi; (8) guru memulai dan mengakhiri proses pembelajaran sesuai dengan waktu yang dijadwalkan.

Seorang guru yang sudah dapat menerapkan pembelajaran I2M3 dalam proses belajar mengajar tentunya hal ini dapat meningkatkan kompetensi seorang guru, terutama kompetensi paedagogiknya. Kompetensi paedagogik seperti yang dijelaskan dalam Peraturan Pemerintah RI No 19 Tahun 2005 meliputi kemampuan mengelola pembelajaran yang meliputi pemahaman terhadap peserta didik, perancangan dan pelaksanaan pembelajaran, evaluasi hasil belajar, dan pengembangan peserta didik untuk mengaktualisasikan berbagai potensi yang dimilikinya. Kompetensi paedagogik ini berkaitan pada saat guru mengadakan proses belajar mengajar di kelas. Mulai dari membuat skenario pembelajaran memilih metode, media, juga alat evaluasi bagi anak didiknya. Karena bagaimanapun dalam proses belajar mengajar sebagian besar hasil belajar peserta didik ditentukan oleh peranan guru. Guru yang cerdas dan kreatif akan mampu menciptakan suasana belajar yang efektif dan efisien sehingga pembelajaran tidak berjalan sia-sia.

Ditinjau dari jalannya acara pelatihan pembuatan dan implementasi perangkat pembelajaran berorientasi I2M3, acara telah berjalan dengan lancar dan tepat waktu. Peserta pun merasa puas terhadap acara yang diikuti dan servis yang didapatkan. Akan tetapi, peserta masih bermasalah dalam pengetikan dokumen. Karena saat pelatihan berlangsung, peserta hanya membuat RPP pada kertas double folio. Peserta mengaku kesulitan untuk pengetikan pada komputer. Dengan demikian, peserta mengharapkan diadakannya pelatihan mengenai penggunaan microsoft word untuk menunjang tugastugas guru.

\section{Penutup}

Dari kegiatan pelatihan pembuatan dan implementasi perangkat pembelajaran I2M3 yang telah dilakukan, maka simpulan dari kegiatan ini yaitu 1) telah terjadi peningkatan pemahaman guru-guru di Gugus XIV Kecamatan Buleleng dalam pembuatan perangkat pembelajaran berbasis I2M3, 2) telah terjadi peningkatan keterampilan guru-guru di Gugus XIV Kecamatan Buleleng dalam mengimplementasikan perangkat pembelajaran berbasis I2M3. 


\section{DAFTAR PUSTAKA}

Arends, R.I. 2004. Learning to Teach. New York, USA. The McGraw-Hill Company.

Dasna, I.W., Sutrisno. 2008. Pembelajaran Berbasis Maslah (Problem Base Learning). Lubisgrafura/wordpress.com/htm. Diakses tanggal 18 Februari 2012.

Depdiknas. 2003. Peraturan Pemerintah nomor 19 Tahun 2005, tentang Standar Nasional Pendidikan, Jakarta.

Depdiknas. 2007. Peraturan Menteri Pendidikan Nasional nomor 41 tahun 2007, tentang Standar Proses Untuk Satuan Pendidikan Dasar dan Menengah, Jakarta.

Nur, Muhammad. 2004. Pembelajaran Koperatif. Surabaya. Pusat Sain dan Matematika Sekolah, UNESA.

Nur, Muhammad. 2005. Guru yang Berhasil dan Model Pengajaran Langsung. Surabaya. LPMP Jawa Timur, Dirjen Mandikdasmen, Depdiknas.

Slavin, R.E. 1995. Cooperative Learning: Theory, Research, and Practice. Massacussett: Allyn and Bacon. 